\title{
Restrictive Business Practices and Competition in the European Economic Community ${ }^{\dagger}$
}

\author{
Leo Spier*
}

\begin{abstract}
A RTICLES 85 and 86 of the Rome Treaty $^{1}$ are designed to proscribe A restrictive trade practices in order "to promote throughout the
\end{abstract} [European Economic] Community a harmonious development of economic activities, a continuous and balanced expansion, an increased stability, an accelerated raising of the standard of living and closer relations between its Member States." More specifically, article 3 of the Treaty states that the Community's objective is to harmonize national principles towards a common policy "ensuring that competition shall not be distorted in the Common Market."

It is open to question whether the EEC law can reconcile divergent national principles by use of a single criterion on competitive practices or whether it will serve more as an administrative umbrella under which national principles will be nodified. Indeed, would such harmonization be in the best interests of the European Economic Community, since it would affect not only disparate economic values, but the divergent social and pohtical norms by which each country ineasures the conduct of competition? First, the differing social and poltical values and economic needs of the Member States preclude agreement upon a common defimtion of competition. ${ }^{4}$ Second, a uniform interpretation of competition

$\dagger$ Research for this article was conducted under a grant from the Institute of Business and Economic Research, University of California, Berkeley.

* Assistant Professor of International Business, University of California, Berkeley. The author gratefully acknowledges the research assistance of Robert Pecota, student in the Graduate School of Business, University of California at Berkeley.

1 Treaty Establishing the European Economic Community [hereinafter cited Roune Treaty], March 25, 1957, 298 U.N.T.S. 11 (1958). Reg. no. 17, 5 Journal OfFictaI des Conaronattes Européennes [hereinafter cited as J.O.C.E.] 204 (Feb. 21, 1962), as amended by reg. no. 59, 5 J.O.C.E. 1655 (July 10, 1962), reg. no. 99/63, 6 J.O.C.E. 2268 (July 25, 1963), reg. no. 118/63, 6 J.O.C.E. 2696 (Nov. 5, 1963) and reg. no. 27, 5 J.O.C.E. 1118 (May 3, 1962), as amended by reg. no. 153, 5 J.O.C.E. 2918 (Dec. 24, 1962) provide the first ordinances which implement the policies of the European Common Market on restrictive trade practices under articles 85 and 86 of the Roune Treaty. Regulation 17 deals with the substantive provisions of the articles, whereas regulation 27 deals with administration.

2 Rome Treaty, art. 2, 298 U.N.T.S. 15 (1958). (Einphasis added.)

8 Rome Treaty, art. 3 (f), 298 U.N.T.S. 16 (1958).

4 As Grisoli stated: "[I]t would be futile to attempt to eliminate some phenomena, which might be labeled 'distortions' of competition under an all-inclusive interpretation, resulting from the variations in the poitical and economic structures of the Member States." Grisol, The Impact of the European Economic Community on the Movement for the 
under the Treaty's antitrust provisions could require the Member States to relinquish more control over their economies than they have evinced willingness to do. ${ }^{5}$ Third, as a matter of economic policy for the Community as a whole, the goal of balanced expansion will require application of different norms for different economic regions within the Six. Therefore, we may expect to see the Community authorities vary their interpretations of articles 85 and 86 to take into account the local objectives and values of the Member State concerned in each case. ${ }^{\circ}$

The hypothesis of this study is two-fold. First, given the reluctance of the Member States to relinquish authority, the EEC's supranational powers will be exerted only moderately, avoiding direct confrontation in cases of national opposition. Second, given the economic and political divergencies of the Member States and the objective of balanced expansion, the EEC Commission will have to rely more upon decisional law and the case-by-case method of elaborating law than is traditional with courts of civil law countries. ${ }^{7}$ This provides the Commission with more flexibility for interpreting each case according to its own economic and political merits within the local framework; thus the Commission has an opportunity to apply the law more stringently than would be possible by strict adherence to the narrow wording of the Treaty provisions. Moreover, decisional law will become necessary to cope with the increasingly diverse market. Thus the issue will be not so much whether the case fits within the perimeter of the specific regnlation, but whether the de facto conditions warrant application of the rules.

Unification of Law, 26 LAW \& ConTemp. PRoB. 418, 422 (1961). See generally van Themaat, Antitrust and the Common Market, 33 N.Y.U.L. REv. 434 (1963).

To appreciate some of the difficulties in framing a consistent interpretation of any common policy in the Community, one need only note the recent show of force required by President de Gaulle to achieve agreement on a common agricultural policy. Other symptoms supporting this postulate are the increasing signs favoring confederation over a federated system, and the continued division on a conmon policy of action for NATO. See generally DeGaulle Charts a Collision Course, Business Week, Nov. 14, 1964, p. 130; Without France, The Economist, Nov. 14, 1964, p. 671; Eyeless in Paris, The Economist, Nov. 7, 1964, p. 571.

5 See Reuter, Juridical and Institutional Aspects of the European Regional Communities, 26 LAw \& Contemp. Prob. 381, 390 (1961).

6 " $\mathrm{It}$ would, however, be very wrong to interpret [the common policy on competition] ... as meaning that the economic peculiarities of the Member States or their natural conditions of production must be adapted to one another as an ond in itself." von de Groeben, The Cartel Legislation of the European Economic Community in Light of Two Years' Experience, in 1 CARTEL AND MoNopolx IN MODERN LAW 63, 64 (1961). Further, the national laws will continue to apply for all matters of restrictive busimess practices that will not affect trade between the Member States (such as intrarational trade or trade with nonmember countries).

7 See generally Lawson, A Comaron Lawyer Looks at Civin Law (1953); MacMmian, Two Ways of ThrnkInc (1934). 
This hypothesis implies that the apparent embodiment of six national laws in the EEC antitrust regulations will not provide a single, uniform reference for the entrepreneur operating in the Common Market. Moreover, as the political and economic conditions of the Member States change, the Commission, in order to maintain balanced expansion, will find it increasingly necessary to re-evaluate prior decisions. This will make it more difficult to predict the outcome of future antitrust decisions solely on the basis of the EEC rules. Therefore, the national antitrust laws may provide more accurate criteria in the near future, because they reflect the economic, political, and social environments of the respective Member States. ${ }^{8}$ Moreover, because national agencies will often administer and apply the Rome Treaty's antitrust provisions, ${ }^{9}$ national attitudes may influence the Commission's decisions.

This article analyzes the antitrust policies of the Six and the role these policies will play in Community decision making on antitrust policy. We first examine the meaning of competition in the United States, the countries of the European Economic Community, and the European Coal and Steel Community. (The Rome Treaty applies to all enterprises that do not fall under the Coal and Steel Community's jurisdiction. ${ }^{10}$ United States' laws may apply to an American or foreign firni if there is an effect on American domestic conditions. ${ }^{11}$ ) We next examine the application of these principles to restrictive trade agreements and dommant

${ }^{8}$ Spaak and Jaeger argue that the national laws of competition are an end in themselves because they are founded on economic principles and ethical values. On the other hand, the EEC laws of competition were created before such values for Europe evolved. They are, therefore, only a means to an end-uniform economic and pohtical values. Spaak \& Jaeger, The Rules of Competition Within The European Common Market, 26 LAW \& Contentr. Prob. 485, 486-87 (1961). See also Jonnt Econ. Conar., Private Trade Barriers and the Atlantic Community, 88TH CoNG., 2d Sess. 1 (1964) [hereinafter cited as JonvT ECON. Conar.].

8 "Since the Commission lacks its own administrative machinery in the territories of the Members, it will normally request national authorities to carry out its investigations." Honig, Brown, Gleiss \& Hirsch, Cartex LAW of the European Economic Conomunity, 70 (1963).

10 Rome Treaty, art. 232, 298 U.N.T.S. 90 (1958).

11 See, e.g., United States v. Aluminum Co. of America, 148 F.2d 416 (2d Cir. 1945); United States v. Imperial Chem. Indus., 100 F. Supp. 504 (S.D.N.Y. 1951), decree 105 F. Supp. 215 (S.D.N.Y. 1952). See also Jornt Econ. Conar. 18.

There is one guideline for the American entrepreneur with respect to the effect of U.S. regulations on his European business operations: They will apply whenever the operations affect domestic conditions. Agreements among subsidiaries are permitted, but not with third parties. Acquisition of foreign firms that affect U.S. trade may be in violation of U.S. Iaws. For a detailed discussion of the effects of U.S. laws on business operations, see van Cise, The Application of the U.S. Antitrust Laws to the European Comninnity, 6 ANTITRUST BULI. 145 (1961). See also Restatement, Foreign Relations LaW of the Untted States \& 18(b) (1962). 
position enterprises. Finally, we analyze the 1964 decision of the EEC Commission in the Grundig-Consten agreement case ${ }^{12}$ to determine the potential significance of national environments in applying EEC antitrust regulations. ${ }^{13}$

NATIONAL ATTITUDES TOWARD COMPETITION

A major goal of the EEC is to ensure undistorted competition ${ }^{14}$ in order to bring about the harmonious development of production and consumption in all Member States. Article 29 of the Rome Treaty states that:

The Commission shall be guided by:

... (b) the development of competitive conditions within the Community to the extent to which development will result in the increase of the competitive capacity of the enterprises;

... (d) the need for avoiding serious disturbances in the economic life of Member States and for ensuring a rational development of production and an expansion of consumption within the Community. ${ }^{16}$

The indefinite wording of this article illustrates its flexibility. What is the criterion for distortion of competition? How does one determine the competitive capacity of enterprises? Section (d) only partially answers these questions. It emphasizes the Community's recognition of the need for inaintaining an orderly economic life within each Member State.

Because of the various economic needs and social and political values, antitrust philosophies range from the neo-liberal view of strict regulation (the United States) to the notion that restrictive trade practices

12 Decision of the Commission, Sept. 23, 1964, 7 J.O.C.E. 2545 (1964).

13 There have been many analyses of restrictive tracle practices in the European communities. Most of them stressed the legal aspects, rather than the social, political, and economic factors. This study is primarily concerned with the latter. Consequently, only excerpts of pertinent regulations are mentioned. For an exhaustive analysis of the law, sce INSTITUT FÜR AUSLÄNDISCHES UND DNTERNATIONALES WTRTSCHAFTSRECHT AN DER JOHANNWOLFGANG-GOETHE-UNIVERSTÄT FrANKFURT AM MATN, KARTEIIE UND MONOPOLE IN MODERNEN Recet (1961); Organjzation for Economitc Co-operation and Development, Gutde to Legislation on Restrictive Trade Practices; Riesenfeld, The Protection of Com petition, in 2 American Enterprise in the European Common Market: A Legal Profite 197 (1960); Riesenfeld, Antitrust Lawes in the European Economic Community, 50 Carrs. L. REv. 459,829 (1962).

14 Rome Treaty art. 3(f), 298 U.N.T.S. 16 (1958).

15 Rome Treaty art. 29(b), (d), 298 U.N.T.S. 26 (1958). [Emphasis added.] For a more detailed legal exposition of competition, sce Comité Intergouvernemental créé par la Conférence de Messine, Rapport des Cleefs de Délégation aux Ministres des Affaires Etrangères (Brussels, April 21, 1956), cited in Riesenfeld, The Protection of Competition, sulpra note 8 , at 204. 
often enhance competition (Belgium and Italy).${ }^{16}$ What, then, are the nature, scope, and bases for competition in the respective countries?

\section{A. United States}

In the United.States, freedom to compete implies the absence of restrictive trade practices. ${ }^{17}$ The antitrust philosophy of the Sherman ${ }^{18}$ and Clayton ${ }^{19}$ acts embodies this concept of hard competition; regardless of alleged benefits to the economy, a business practice may not substantially lessen competition. ${ }^{20}$ While it is difficult to generalize about the U.S. antitrust laws, restriction of competition in private business is generally considered bad per se and is, therefore, prohibited a priori in contrast to most European systems. There are several economic, social, and political conditions underlying this philosophy. First, there is a large national economy with many large and efficient firms, making it less necessary for the Government to provide special exemptions for those firms adversely affected by the antitrust laws. Second, the economy is generally consumer oriented. Third, there is relatively little dependence upon exports and, therefore, less interest in the use of cartels to improve the nation's competitive export position. Finally, there is a strong propensity for individual freedom--based on the equal right to acquire property-and for "achieving freedom from corruption and maintaining freedom of independent thinking in political life."21 The laws against restriction of competition depict part of this philosophy by protecting the individual consumer from possible ill effects of monopolies

16 Competition has been construed within the EEC in four ways: the neo-liberal school, which draws from the American concept that restrictive trade practices are harmful per se and must be forbidden a priori; the laissez-faire view, arguing for a posteriori control over the abusive aspects of restrictive trade practices; the concept likely to be accepted by the EEC Commission, that restrictive trade practices must be adjudicated in the light of the peculiar local economic conditions (differing from the laissez-faire view mainly with respect to control procedure); and the "technical progress" view, encouraging restrictive trade practices to develop productive capacity, based on the theory that competition is not an end in itself-the aim is economic progress. Cartel Policy and the Common Market, 28 Politicat and Economirc Planning [hereinafter cited PEP] 201, 206 (1962).

17 There are, of course, exceptions to this attitude, such as fair-trade pricing and patent and licensing agreements, which for all purposes amount to restrictive trade practices.

1826 Stat. 209 (1890), as amended, 15 U.S.C. $\S \S 1-7$ (1964).

1938 Stat. 730 (1914), as amended, 15 U.S.C. $\$ \$ 12,13,14-27$ (1964).

20 See Brewster, ANitTrust and AMrerican Business Abroad 42 (1958), cited in Spier, The German Cartel Law: An Attempt to Eliminate the Restraint of Competition, 20 WaSH. BUs. REv. 19, 21 (1961).

21 Thorelti, The Federal Antitrust Policy 227 (1955), quoted in Hofstadter, What Happened to the Antitrust Movement?, in THE BuSINESS ESTABLISHMENT 113, 120 n.6 (Cheit ed. 1964). 
and collusive business practices and by providing entrepreneurs access to an open market.

In Brown Shoe Co. v. United States, ${ }^{22}$ the Supreme Court held illegal under section 7 of the Clayton $\mathrm{Act}^{23}$ a merger that would have given Brown Shoe control of only four and one-half per cent of the nation's shoe production and about seven per cent of the nation's retail shoe stores. The Court condemned "bigness" derived through corporate acquisitions primarily because of a conceivable injury to the American concept of competition; it was concerned only secondarily with injury to the small competitor. Section 7 effectively covers all possible mergers deemed contrary to the American concept of free competition. ${ }^{24}$ In the United States, therefore, antitrust regnlation seeks to preserve competition and to uphold a more classic economic concept and pluralistic social philosophy. This philosophy generally allows no restrictive practice to lessen competition regardless of any alleged economic gain or loss to the nation.

\section{B. Countries of the European Economic Community}

The economies and social and political norms of the European countries differ considerably from their American counterparts and from eacli other. As a result, their concepts of competition differ. The market size of each Member State tends to be sufficiently small so that a change in the structure of industry could seriously affect the national economy. ${ }^{24 a}$ Exports play a major role; the efficiency of a firm must be measured against that of foreign competitors often many times its size. The capital goods industries-a major export factor-traditionally have a low turnover, making them more vulnerable to economic fluctuations and therefore in need of protection. Finally, political and social goals play a major part in the economic planning of the European economies; this requires safeguards to achieve optimum economic stability, thus ensuring against unexpected fluctuations associated with "free competition."

\section{Germany}

To the Germans, who allegedly modeled their new cartel laws after the American antitrust legislation, laissez-faire competition means the

22370 U.S. 294 (1962). See also United States v. Continental Can Co., 378 U.S. 441 (1964); United States v. Penn-Olin Chem. Co., 378 U.S. 158 (1964); United States v. Aluminum Co. of America, 377 U.S. 271 (1964); United States v. Bethlehem Steel Corp., 168 F. Supp. 576 (S.D.N.Y. 1958).

2338 Stat. 731 (1914), as amended, 15 U.S.C. $\$ 18$ (1964).

24 See United States v. Philadelphia Nat’ Bank, 374 U.S. 321, 342 (1963).

24a For example, in 1964, General Motors' sales of $\$ 16.9$ billion equalled the sales of the one hundred largest French firms and equalled $80 \%$ of the French national budget. I'Express (Paris), Oct. 4-10, 1965, p. 40. 
freedom to develop productive capacity protected from the risks of "ruinous" competition. ${ }^{25}$ The German jurist, Hans Lutz, clearly stated a major German view of competition:

It should be kept in mind that free competition also has definite undesired effects upon the economy; . . . limitless competition may cause devouring price wars, squandering of resources, and cartelization.

Restraint of competition is often indispensable in innumerable markets to assure greater productivity, a more equitable distribution of income, as well as better distribution among consumers. It should not be overlooked that it is unthinkable to have a stable development of the economy and stable prices without a stable basis for existence and profitability. ${ }^{26}$

This view has given rise to legislation which, in reahty, considerably modifies a priori prohibition. German law is permeated with statutory exemptions designed to allow cartels and dominant enterprises to achieve productive efficiency so that German industry can effectively compete with the industrial giants of other nations. ${ }^{27}$ Germany's capital goods industry provides over fifty-five per cent of the country's exports; ${ }^{28}$ being one of the mainstays of the German economy, it requires special protection. Therefore, in the German social market economy, the concept of competition approaches that of a guarantee for orgamining privately one's own business affairs with little fear of antitrust intervention. Despite some recent tendencies favoring the consumer, this freedom from intervention, based upon Germany's production-oriented value system, still prevails. ${ }^{29}$

The social values of order, security, and stabihty underlie this desire for productive performance. To the German, these values are often more important than the chance to gain money. He would rather preserve his status and protect his position. ${ }^{30}$ The productive strength of a cartel

${ }^{25}$ Schwartz, Antitrust Legislation and Policy in Germany-A Comparative Study, 105 U. PA. L. Rev. 617, 620 (1957).

${ }^{26}$ Lutz, Gesetz gegen Wettbewerksbeschränkungen, NeUE JURISTISCHE WOCHENSCHRIFT 1298 (1957).

27 See the appendix to this article for a summary of the political, economic, and social factors from which each Member State's concept of competition is derived. The appendis also details the more important provisions of each nation's law and compares them with the EEC and ECSC provisions.

28 In 1963 total German exports amounted to DM 58.3 billion, of which 32.1 billion (or 55.1\%) were capital type goods. Statistisches Bundesamt, Statistisches Jakrbuce FÜR DIE BUNDESREPUBLIK DEUTSCHLAND 1964, at 321 (1964).

29 See Waltich, Mainsprings of the German Revivad 332-38 (1955).

30 See Id. at 330, 333. See also MuHLEN, The Return of Germany 95 (1953): "The Germans preferred to let the precarious public affairs be performed by the few who feel inspired to do so, while the people at large devoted themselves with great industriousness to their production ...." 
or a dominant position enterprise provides assurance for the desired security and stabihty-protection from "ruinous competition." Thus, legal exemptions from the antitrust laws ensure that cartel agreements which meet certain minimal conditions will be permitted..$^{31}$ Moreover, within this philosophy of competition, mergers that tend towards dominant positions are generally not prohibited. This is evidenced by the implicit acquiescence of the cartel authorities to the acquisition in 1959 of the Bayrische Motoren Werke by Daimler-Benz, giving the latter over twenty per cent of the German autonıbile market, plus a diversity of cominercial lines. ${ }^{32}$ Contrast this attitude with the decision in the Brown Shoe case.

\section{France}

In France, the concept of competition depicts the orderly and united conduct of business within the framework of a nationally planned economy. ${ }^{33}$ Freedom of competition must fit the plan of the economie "concertée." Three conditions mold this French attitude. First, the French still ain toward further consolidation of small unproductive enterprises. ${ }^{34}$ Second, since July 18, 1952, an escalator clause in the wage structure requires price controls $\mathrm{m}$ order to avoid inflation. ${ }^{85}$ Finally, freedom of contract-a strong social and pohtical trait of French individualisn-may conflict with freedom of competition, since contracts often underlie restrictive trade practices. It is not surprising, therefore, that monopohistic practices and private cartels are still a part of the industrial pattern in France. ${ }^{36}$ Moreover, it is believed that large enterprises are more likely to bring about improved standards of living through technological innovations, a higher rate of production, and lower costs. ${ }^{37}$

The Technical Commission, the administrative agency in charge of mvestigating concerted restrictive trade practices, has stated that, for France, free competition is not the only solution. The law is not opposed to either a cartel or a governnient controlled limitation of competition if

31 Hirsch, Kontrones WrRTSchafiticher Macht 18 (1958), cited in Graupner, The Law Relating to Restrictive Trade Practices in West Germany and in the Treaty Establishing the European Economic Community, Comparative Aspects of Restrictive Trade Practices, INT'I \& COMP. L.Q. SuPp. No. 2, at 41, 50 n.2 (1961).

32 For an account of the acquisition, see Business Week, Nov. 21, 1959, p. 135.

33 See The Economist, March 14, 1964, pp. 969-70. (1963).

34 See Sheafan, Promotion and Control of Industry in, Post-War France 42, 45 259.

35 [1952] Journal Officiel [hereinafter cited J.O.] 7227; [1952] Rec. Dalloz Législation

${ }^{36}$ See SHEAHAN, op. cit. supra note 34 , at 45.

37 Eirtarand, Organized Bustness in France, 488-89 (1957). 
the economic effects on prices, are better than those that would result if competition was left free to operate. ${ }^{38}$ Concentration that brings about a rise in the general productivity of the industry is encouraged..$^{39}$ Therefore, restriction of competition per se is permissible as long as it is in the public interest and as long as it does not inflate prices abnormally, thereby upsetting a planned economy.

The vagueness of the concept of public interest lends the French much flexibility in the regulation of competition. Only abusive actions are prohibited on the basis of a posteriori regulations; the determination of the meaning of "abusive" is a responsibility of the Technical Commission. Article 59 ter $(1 \& 2)$ of Ordinance No. 45-1483 gives the Commission the authority to exempt cartels that "improve or extend the market for the products in question or insure further economic progress by means of rationalization and specialization." ${ }^{\prime 0}$ The French antitrust legislation is, then, the distinction between structural power-desirable per se-and monopolistic (abusive) behavior-to be regulated if it adversely affects the national economy.

\section{Belgium and Luxembourg}

In Belgium, regulation of competition "was directed toward trust boosting-not trust busting." ${ }^{41}$ Similar to France, the Belgian government permits restriction of competition so long as it is not contrary to the public interest. The producer is considered a more important element in the Belgian economy than the consumer. Freedom of competition tends to become freedom to stave off competition. Because Belgium's exports account for over thirty per cent of the gross national product, ${ }^{42}$ production and market regulations are thought to be absolutely vital. Moreover, the government often invites certain restrictive trade practices to improve the domestic firms' ability to compete in foreign markets. ${ }^{43}$ The government considers the fact that Belgium has the EEC's highest ratio of firms with fewer than fifty employees to be detrimental to its exportcompetitive position. ${ }^{44}$ The firms are said to operate at high costs and

38 Coaranssion Technioue des Ententes, Rapports au Ministre Charge des Affatres EconomTQUes pOUR LES ANNÉEs 1954 A 1959 [hereinafter cited COMnM'N REP.] 45 (1961). 39 Id. at 18.

40 Ord. No. 45-1483 of June 30, 1945, [1945] J.0. 4150, [1945] Sirey Lois Annotées 1898, as amended by Decree No. 53-704 of Aug. 9, 1953, [1953] J.0. 7045, [1953] Bulletin Législatif Dalloz 587.

41 Jonnt Econ. Comar. 9.

42 Office Statistique Des Communautés Européennes, Butretrin Général de StatisTIQUES, No. 12, at 12 (1964).

43 Adequate Competition Regulation for the European Economic Community, Wirtschaftsdienst (Hamburg, June 1961).

44 Report of a seminar held by the Department of Applied Economics, Free University 
low overall profits. Although the profit per unit product is high, the number of units sold in this himited national market is so low that overall profit margins are still very narrow. Inefficient utilization of economic resources might be increased by competition between small concerns, resulting in possible unemployment and abnormal deflation trends. The Belgian government therefore considers it in the public interest to protect the producer; the national economy takes precedence over individual freedom ("union fait la force").

Freedom of association, which is conducive to restrictive trade practices, has been upheld by the Belgian Supreme Court: "The courts cannot eliminate the free contract in order to better the position of a losing party." ${ }^{\prime 4}$ Restriction of competition, then, becomes abusive only when it violates the public interest. This is seldom the case, however, since the Economic Council of the government, in the public interest, aims for greater concentration in production to compete in exports.

Luxembourg's attitude toward competition is comparable to that of Belgium because of the close economic and political ties between the two countries.

\section{The Netherlands}

In the Netherlands, the criterion for competition is based on the "general interest." "A grim fight for economic survival ... . [has given the Hollander] a sense of order [and] ... an inclination toward cominunal organization ...."46 The government's economic planning and restructuring of the Dutch enterprise system has been considered an essential ingredient in the betterment of national hiving standards. Restrictive trade practices have become an integral part in the national policy making of the Dutch; one observer feels that "it is doubtful whether the Dutch would have succeeded in keeping their prices competitive and their wages below average had the employers been less willing to accept a fair measure of official interference in the matter of prices and profits ...." ${ }^{\prime 4}$ Because of their sense of communal orgamization, the Dutch readily accept governmental interference in business in the national economic interest. The purpose of regulation of restrictive

of Brussels, L'insuffisance des investissements, motif de l'insuffisance de l'expansion belge?, 1961 Camiers Economiques de BrUXxelres 493, 505 (1961). The author does not support the behief that small firm size necessarily leads to inefficiency.

45 Société de Personnes à Responsaljilité Limitée Etablissements Gripekoven c. Association Sans But Lucratif "Reglémentation-Union Spépha," Cour de Cassation (1'ro ch.), June 2, 1960, [1960] Pasicrisie Belge 1133, 1136; 15 Revue Critique de Jurusprodence BelGe 206 (1961).

46 Schorr, The Dutch Way of Life, in BENELuX 1958, at 212 (1958).

47 Lewandowsky, Recent Trends in the Dutch Economy, 20 The Worad TOday 403 (1964). 
trade practices is to improve ability to compete abroad. Thus the Economic Competition Act of 1956/58 considers restrictive trade practices per se as neither good nor bad, making the legislation "an essentially flexible instrument at the service of economic policy"48 by prohibiting abusive practices a posteriori.

Even thougln the laws protecting competition indicate stricter potential regulation than those of Belgium, Holland's dependence upon exports, and the government view that the average Dutcli firm is of a small, uneconomic size generally result in lenient application of the law. ${ }^{49}$ Competition, therefore, is a function of the economic needs of an exportdependent country that is mainly composed of small businesses.

\section{Italy}

Italy has no law regulating or protecting competition. Italian legislation has gone no further than proscribing the pirating of products, trademarks, or tradenames. ${ }^{50}$ There are three reasons for the lack of any definite regulation of competition. First, Italy has conflicting economic standards. It must encourage agreements and dominant positions in the underdeveloped South in order to create and improve industrial capacity in that area; on the other hand, it must provide austere measures agaimst the restrictive trade practices of such industrial giants as Montecatini or Pirelli ${ }^{51}$ in the well-developed North. Second, many concerns, such as the Institute of Industrial Reconstruction and the National Hydrocarbon Agency, are holding conpanies owned wholly or largely by the government, which is not mterested in divesting itself of this political power over the economy. Third, political factionalism among the Italians has contributed to continued rejection of any proposed antitrust legislation. Hence, the courts, under the Civil Code, have generally condoned restrictive trade practices. ${ }^{52}$

\section{European Coal and Steel Community}

The European Coal and Steel Community (ECSC) forbids or allows restrictive trade practices as the case may require. "The practical alternative in industries like coal and steel is . . . between different degrees of

18 PEP 224.

49 The confidential register of restrictive practices showed 1408 agreements as of January 1961. Jonnt Econ. Comm. 16.

50 Cóprce Crvme art. 2598 (Italy 1942). See generally Venturini, Monopolies and Restrictive Trade Practices in Italy, 13 INT'工 \& CoMr. LAW Q. 648 (1964).

51 See generally Voxaw, The STX-LegGed Dog 74 (1964). See also Lessons for Regions, The Economist, Nov. 7, 1964, pp. 615, 616.

62 See Societa Motta c. Zunella \& Donaldini, Corte Suprema di Cassazione, March 2, 1961, [1961] II Foro Italiano 770. 
oligopoly, not between oligopoly and perfect competition." ${ }^{\text {"63 }}$ Because of the economic importance of the basic coal and steel industries, the High Authority insists on relatively strict supervision of restrictive practices that could have destabilizing effects on the economies of the Member Countries. Article 2 of the ECSC Treaty imphicitly grants this supervision: "[T] he Community must progressively establish conditions which will within themselves assure the inost rational distribution."

Since coinpetition contains disparate values for different Member States and since "ruinous price competition" is considered by Europeans as inherently unstable, the ECSC regulation purposely leaves "an air of ambiguity in the principle of the Treaty, providing ... [them with] a flexible concept of competition." States' former pro-trust policies favoring the steel and coal cartels have been continued despite, or perhaps because of, supervision by the ECSC High Authority. As one observer noted, "Although the Community at times resembles a laissez-faire system, it is obviously assunied that its economic aims cannot be accomphshed by the automatic play of supply and demand. The competition established in the common inarket is not free, but loyal and regulated." ${ }^{216}$ Thus, as of January 31 , 1964, the ECSC prohibited less than three per cent of the applications for restrictive trade agreements. ${ }^{57}$

\section{The European Economic Community}

Article 29 of the Rome Treaty states that the Commission, in inplementing the EEC's antitrust pohicy, must be guided by the "developinent of competitive conditions" for the purpose of "rational development of production and consunption within the Community" without seriously disturbing the "economic hife of Member States." The antitrust policy, which is designed to eliminate distortion of competition, faces the task of harmonizing the divergent concepts of (1) Germany, which permits restrictive trade practices if they secure and improve the productivity of the national economy, (2) France, which condones such practices if they do not upset national planning of industrialization and if they avoid inflation, (3) the Benelux states, which in the public interest may encourage restrictive trade practices that increase the firms' scale of plant in order to improve export competitive position, and

53 Lister, Europe's CoAt and Steet, Community 174 (1960).

54 Treaty Establishing the European Coal and Steel Community, April 18, 1951 [hereinafter cited as Paris Treaty], 261 U.N.T.S. 140 (1951).

55 BURN, THE STEex INDUSTRY 1939-1959, at 398 (1961).

56 Mason, The European Coal and Steet Community 71 (1955).

57 High AUthortty, Twelfth General Report on tHe Activities of the COMMUNITY 190-95 (1964). 
(4) Italy, whose economic dichotomy, political fragmentation, and freefor-all practices dictate no definite pohicy on competition. ${ }^{68}$

The implementation of the Rome Treaty's articles 85 and 86 on restrictive trade practices, then, must allow for a wide range of interpretation to accommodate the politico-economic requirements of Member States and the separate application of the laws of the European Coal and Steel Community. Therefore, hiteral interpretation of EEC law may no longer be possible as is the case with the antitrust laws of the Member States. Instead, the local environments will provide the foundation for interpretation of the Community law. As a result, the Commission will have to make more use of case law than courts traditionally have done in the European civil law countries.

The seemingly intentional vagueness of wording in the EEC text on distortion of competition, and the broad treatment of restrictive trade practices support this hypothesis. According to article 248 of the Treaty, the French, German, Itakian, and Dutch versions of the Treaty are equally authentic and bimding. Yet in some respects they are dissimilar; for example, article 85 of the French text (like the unofficial English) states that violation of restrictive trade practices must be "likely" to affect trade, whereas in all other texts, it must "harmfully" affect trade. ${ }^{59}$ The difference implies the greater strictness of the Frencli law. Therefore, in the official translation of the text, as in the unofficial Englisl, the EEC regulations are fitted to the French needs to "avoid serious disturbances in the economic life of the Member States."

Similarly, according to the EEC laws, restrictive trade practices must "adversely affect competition," rather than, as the ECSC treaty provides, "tend to affect normal competition." Any criterion for competition in the absence of a "norm" and within the vagueness of "adverse

58 The differences in the national meanings of competition shown in the text are further complicated for the businessman by the separate application of the laws of the ECSC and of the U.S. The ECSC may permit restrictive trade practices in coal and steel industries in order to stabilize economic conditions, but it will retain the right to guide the restraining practices. The U.S. antitrust laws make free competition inviolable and therefore severely curtail agreements and mergers that may affect domestic consumers. Yet the U.S. condones restraints such as licensing agreements or patents (which may hinder productive capacity) more readily than most European countries, which are less concerned with the consumer than with the production of their economies. Of course, as Buxbaum noted, "[T] $]$ he position of the Commission on the entire patent-antitrust relation las not yet jelled." Buxbaum, Restrictions Inherent in the Patent Monopoly: A Comparative Critique, 113 U. PA. L. REV. 633,657 (1965).

59 Thiesing, Rules Governing Competition Within the European Regional Communities,

26 LAW AND Contemir. Prob. 464, 471 (1961).

60 Rome Treaty art. 29 (d), 298 U.N.T.S. 26 (1958).

01 Riesenfeld, The Protection of Competition, in 2 AMrERICAN ENTERPRISE IN THE EUROpean Conaron Market: A Legal Profine 197, 327 (1960). 
effect" must be built upon the factual conditions of each nation rather than upon the letter of the supranational law. The EEC, in contrast to the ECSC, must therefore find more distinct restrictive trade practices to warrant application of the rules.

The Commission under EEC article 85(3) may declare the Treaty's provisions inapplicable if certain conditions are met; the effect is that virtually any agreement can be exempt from EEC scrutiny if local needs warrant. ${ }^{62}$ The Spaak Report pointed out that such measures would be required for the EEC to conciliate different mass production techniques with maintenance of competition. ${ }^{63}$ For these reasons, the EEC will tend to "harmonize" the national laws against restrictive trade practices between Member States rather than to find some "uniform" denominator similar to that of the ECSC.

\section{II \\ REGULATION OF COMPETITION}

The differing concepts of competition among the Member States make it necessary to examine the national laws on (1) restrictive trade agreements and (2) dominant positions because the national laws are direct derivatives of these concepts. This becomes especially significant when one remembers that article 85 on restrictive trade practices and article 86 on dominant positions will be apphed according to the diverse concepts of competition among the Member States. For this reason, this article will discuss restrictive trade agreements and dominant positions in that order, using the more familiar regulations in the U.S. as a basis froin whicls to start.

\section{A. Restrictive Trade Agreements}

Sections (1) and (2) of article 85 of the Rome Treaty prohibit and render void "any agreement between enterprises, any decision by associations of enterprises and any concerted practices which are likely to affect trade between the Member States and which have as their object or result the prevention, restriction or distortion of competition within the Common Market ...."."

As illustrations, the article lists: (1) fixing prices and trade conditions; (2) restricting production, markets, technical development or investment; (3) sharing markets or sources of supply; (4) applying

62 Rome. Treaty art. $85(3), 298$ U.N.T.S. 48. "Inapplicability" provides one of the most effective escape clauses in the law.

63 PEP 260.

64298 U.N.T.S. 47 (1958). 
unequal terms for equivalent supplies; and (5) making the sale of one product conditional upon the sale of another but unrelated product. ${ }^{65}$

The a priori prohibitions of sections (1) and (2) of article 85 seem to resemble closely the antitrust legislation of the United States. The relatively strict attitude of the U.S. is exemplified by the electrical equipment price fixing cases ${ }^{6 \mathrm{~b}}$ where the court considered conspiratorial price fixing to be a violation prohibited a priori and even prescribed thirty-day criminal sentences in addition to substantial fines. Moreover, the WebbPomerene escape clause, ${ }^{67}$ granting exceptions for U.S. participation in export cartels, has been rather meffective, because it is virtually impossible to find actions which are not in restramt of domestic competition; as of 1962, registration under this act had dwindled to twenty-nine associations. ${ }^{68}$

\section{Germany}

The a priori prohibitive nature of German regulation is more apparent than real because almost any type of restrictive agreement may be exempted by statute; these exemptions allow agreements for cartels, resale price maintenance of branded goods, exclusive dealings, and certaim other practices. ${ }^{69}$ While the law prohibits liorizontal agreements in the interest of the productive capacity of the economy, it permits vertical agreements for mucli the same reason. Moreover, the "does not apply" clause, like the Rome Treaty's article 85(3), further weakens a priori prohibition. ${ }^{70}$

In Eau de Cologne 4711 v. Farina, ${ }^{71}$ the plaintiff, a manufacturer who practiced contractual resale price maintenance, was awarded damages

65 The recent regulation 19/65, 8 J.O.C.E. 533 (March 6, 1965), provides for group exemptions regarding agreements and concerted practices under article $85(3)$ and regulation 17. Specifically, regulation $19 / 65$ empowers the Commission to exempt an entire class of enterprises from the need for negative clearance if, and only if, it falls within the exemption clause of article 85(3). These class exemptions do not necessarily affect the hypothesis of this essay: As long as regulation 19/65 must operate within article $85(3)$, there will be little chance of across-the-board clearances for all EEC Member State enterprises. Group exemption will have to come within the local economic and political framework in order to achieve balanced expansion in the EEC. Therefore, the differing environments of Southern Italy and Germany, for example, preclude group exemptions for similar classes of enterprise in both areas.

66 See CCH Trade Reg. Rep. II 8801 (1965).

6740 Stat. 516 (1918), as amended, 15 U.S.C. $\$ \S 61-65$ (1964).

68 JonNT Econ. Conn. 20.

69 See-generally Riesenfeld, supra note 61 , at 216-35.

70 Id: at 216.

71 Judgment of Oct. 8, 1958, 28 Entscheidungen des Bundesgerichthofes in Zivilsachen [hereinafter cited BGHZ] 209, 11 NEUE JURISTISCHE WOCHENSCHRIFT [hereinafter cited NJW] 1863. See also Judgment of June 14, 1963, 40 BGHZ 135, 17 NJW 152, in which enforcement of retail prices was held justified-within EEC article 85-so long as "the manufacturer's price maintenance system was in fact ... [not] complete." 
from the defendant, a competitor producing cosmetics. The defendant quoted "non-obligatory" retail prices in price hists, advertisements, and on the product packages. Although the retailers were aware that these prices were not binding, the consumers, unaware of the "non-obligatory" element, purchased at the quoted prices. The court held that the defendant's price quotations, in effect, misled the consumers to believe that the prices were fixed. Such action violated sections 38 and 15 of the Act Agamst Restraints of Competition. Price fixing per se may be permissible; the plamtiff, who practiced contractual resale price maintenance, had registered his agreement with the Federal Cartel Office and therefore had not violated the regulation on restrictive trade practices. However, the defendant's price recommendations, considered by the court to be misleading, were held illegal. ${ }^{72}$

Another case involved a resale price maintenance agreement between a wholesale grocer and a producer of branded liquors. ${ }^{73}$ The wholesaler had informally agreed that in his direct sales to consumers he would adhere to the prices fixed by the producer in the producer's contracts with retailers. The producer subsequently demanded a contractual price agreement but the wholesaler refused. Subsequently, the wholesaler sued the producer for damages resulting from withheld deliveries. The action was dismissed by the court on the grounds that the producer had not violated the Act Against Restraint of Competition by trying to "induce" the wholesaler to agree to a new resale price mamtenance agreement. Thus, a vertical price fixing agreement on branded goods is permissible. The only requirement is that the agreement be registered. ${ }^{\mathbf{7 4}}$

\section{France}

Although the French regulation of restrictive trade agreements apphes only a posteriori, in some imstances it more closely resembles the EEC a priori legislation. Article 59 bis of Ordinance No. $45-1483$ prohibits outright "all concerted actions, agreements, express or tacit understandings, or coalitions, in whatever form and for whatever reasons, which have as their object or may have as their effect a restraint of the free exercise of competition, by hindering the lowering of the costs or prices or by favoring an artificial rise of the prices." 75 This excerpt indicates

72 A vertical price maintenance contract for branded goods may be legally enforced if the agreement is registered with the Cartel Authorities. Law Against Restraints of Competition of July 27, 1957, § 16, [1957] I Bundesgesetzblatt 1084.

${ }^{73}$ Appeal Court of Hamburg, Jan. 19, 1961, "WirTschafr uNd Wetrbewerb [hereinafter cited as WoW] 420 (1961).

74 As of 1962 , less than ten per cent of the cartel agreements and dominant positions had been rejected by the Cartel Office. Jornt Econ. Comar. 14.

75 Note 40 supra. (Emphasis added.) See generally Riesenfeld, supra note 61, at 251. 
that the determinants of a "bad" cartel-most often a vertical cartel, which as we have seen differs from the German concept which disfavors a horizontal cartel-are mainly distortions of prices which may destabilize the economy. Here is one reason for the French text of the EEC antitrust regulations to use the stricter interpretation "likely to affect." Economic progress and improvement of production outlets, however, are rationalizations for a "good" cartel-most often a horizontal cartel. Such a cartel may even be encouraged if it may help to stabilize prices. ${ }^{70}$

The Technical Commission reflected the French attitude in its annual report of 1956: "Concentration on top of its intrinsic advantages, that is to say bringing about a rise in the general productivity of the industry, could lead to the rebirth of greater competition among larger firms . . . . Thus the favorable effects of a cartel [must] ... be traced to the impact of the cartel itself and not to the external circumstances of the market or the business cycle." ${ }^{\prime 77}$ On the other hand, a French court declared a vertical combine in the market for slrellfish null and void. The decision was upheld by the Court of Appeals of Rennes, stating that the combine was in fact an obstacle to the reduction of production costs and selling prices. $^{78}$

In other words, the French do not necessarily consider a combine harmful; rather they are concerned with its effects. "To be permitted, a cartel must justify itself by its favorable effects on the national economy."79 The major criterion for this justification is the effect on price; the French seem to feel that vertical cartels are more likely to destabilize prices than are lorizontal cartels. Any cartel that hinders the reduction of production costs or selling prices or encourages an artificial rise in prices is prohibited. ${ }^{80}$

The French sensitivity to price levels stems from their politicoeconomic plilosoply: Standards of living should be increased by reducing prices and costs rather than by increasing revenues; increased revenues instill fear of inflation and deteriorate the competitive position of France

76 See, e.g., Décision du Ministre on Entente entre fabricants de fils et cables électriques isolés [May 15, 1958] in Comar'N REP. 25.

77 Conar's Rep. 18-19. The Helanca-France syndicate case concerning a cartel in the moss nylon yarn industry further supports the argument that cartels that improve national production and price stability are in fact desirable. Décision du Ministre on Entente dans l'industrie du fils mousse de nylon [Sept. 11, 1962] in CoMnIISsion TECHNioue Des ENTENTES, Rapports Pour les ANNÉEs 1960, 1961 et 1962, at 30 (1964).

78 Sociêté "La Langouste" c. Le Bris, Cour d'Appel de Rennes, June 15, 1961, 24 Drorr Socrat 459 (1961). This combine was declared invalid by the Minister of Economic Affairs after an investigation by the Technical Commission. Décision Ministerielle on Entente pour l'organization du marché de la langouste [Apr. 21, 1960] in Coxar'N REP. 58.

78 CoMar's ReP. 2.

80 Art. 59 bis, note 40 supra. 
in the world market. Therefore, the French prohibit, a priori, agreements that adversely affect prices. Moreover, existing cartels that abuse their positions by adversely affecting prices are considered "bad" and prohibited a posteriori. Even so, there have been very few cases of abuse brought to court because the French, in contrast to the Americans, are reluctant to apply the criminal penalty clause ${ }^{81}$ in the French law.

\section{The Netherlands}

The Netherlands' Economic Competition Act of $1956 / 58^{82}$ suppresses rather than prohibits abusive practices. Cartels are therefore permissible; their only duty is to register with the Minister of Economic Affairs. This registration is to insure supervision over the cartels in order to prevent practices from becoming contrary to the general interest. The general interest becomes formulated through case-by-case interpretation..$^{83}$

In the Pharmaceutische Handelsconventie ${ }^{84}$ case, vertical price maintenance was condoned because it did not adversely affect the general interest. As one observer noted in reference to this case, the government still seemed to be afraid of competitive practices that allow only marginal profits. At this time the government would not go as far as to prohibit the collective maintenance of vertical prices; it only ordered that maximum profit margins should be fixed. ${ }^{85}$

There is httle doubt but that the Dutch government will continue to follow a cartel policy employing the abuse principle. Recent cases which have slrown a stricter application of the abuse principle ${ }^{86}$ do not necessarily indicate a new trend in the Dutch concept of regulation of restrictive trade agreements. One reason is the attitude of the Minister of Economic Affairs, whose prime interest is to maintain an exportcompetitive and stable economy; this is likely to be achieved at the expense of freedom of competition. ${ }^{87}$

81 Ord. No. 45-1484, arts. 40, 42, June 30, 1945, [1945] J.0. 4156; [1945] Sirey Lois Annotées 1907.

82 [1956] Staatsblad van het Koninkrijk der Nederlanden [hereinafter cited as Stb.] 401; [1958] Stb. 412; combined text printed in [1958] Stb. 413.

83 See generally Riesenfeld, Antitrust Laws in the European Economic Community, 50 CALIR. L. REV. 459, 474-78 (1962).

84 Decision of the Minister of Economic Affairs, March 13, 1959, Nederlandse Staats. courant, March 13, 1959, p. 6.

85 See Mok, Application of Cartel Legislation During the Time Mr. de Quay was in Office, 12 Soctaal Economische Wetgewnig, 117, 124 (1964).

${ }^{86}$ See Riesenfeld, Antitrust Laws in the European Economic Community: A Sequel, 50 CALIF. L. REv. 829, 838-41 (1962).

87 See generally Mok, supra note 85 , at 151 . 


\section{Belgium and Luxembourg}

Even though the tenor of the Belgian antitrust act of May 27, 1960, resembles somewhat that of the French law, Belgian enforcement is probably more lement. Based on the abuse concept, a cartel agreement may be considered good or bad depending on its effect upon public interest, that is, on certain government preferences granted by the ArrêteLoi of January 22, 1945. This law gives the Mimister of Economics farreaching powers to plan and regulate the industrial and commercial hife of the nation.

Thus far, refusal to sell is widely practiced, gentlemen's agreements are implicitly permissible, no registration of cartels is required, no civil penalties for abusive actions are provided, and restrictive contractual agreements may be rationahized on the basis of public interest. In Spierkel v. Agence et Messageries de la Presse, ${ }^{89}$ a price fixing agreement between pubhshers, which resulted in a boycott of trade for a single firm, was upheld for the purpose of "protecting trade" in general. Because of its intranational character, it did not fall under EEC jurisdiction.

In a later case, ${ }^{00}$ the Commercial Court upheld an agreement between producers to restrict production of all cements other than natural cement in return for compensation by the association of Belgian manufacturers of artificial Portland cement. This opinion has been vacated by the Court of Appeals, which withheld its own decision pending adjudication by the EEC Commission. Nevertheless, the decision of the Commercial Court indicates the sensitivity toward protecting producer cartels that are deemed vital to the Belgian economy and therefore within the public interest. The reversal by the Court of Appeals dealt primarily with the question of restraint of competition as it affects the Member States under the Rome Treaty, rather than the value of producer cartels. ${ }^{91}$

Luxembourg's Grand Ducal decree of January 22, 1936, provides little guidance. It protects producers, merchants, and consumers against certain activities tending to abuse the normal conditions of competition. Because of the virtual absence of cartel legislation, the Belgian laws probably are the best guide to Luxembourg's practices.

88 [1960] Moniteur Belge 4674, reprinted in 10 WoW 704 (1960).

80 Spierkel c. Agence et Messageries de la Presses, Cour d'Appel de Bruxelles, June 1, 1962, 77 Journar des TrIBUNaUx [hereinafter cited as J.T.] 459 (1962).

${ }^{90}$ Association Générale des Fabricants Belges de Ciment Portland Artificiel c. Carrieres Dufour, Commercial Tribunal of Tournai, Jan. 10, 1964, 79 J.T. 447 (1964).

91 Association Générale des Fabricants Belges de Ciment Portland Artificiel c. Carrieres Dufour, Cour d'Appel de Bruxelles (5e ch.), June 25, 1964, [1964] Pasicrisie Belge II 129, 79 J.T. 576 (1964). 


\section{Italy}

Except for the Civil Code of $1942,,^{\circ 2}$ Italy has not yet established any anti-cartel legislation. Compulsory cartels are still evident, resale price maintenance is an established practice, and predatory price cutting is considered legal. ${ }^{93}$

The Colombo bill of 1959,04 drafted by the then Minister of Industry and Commerce, was one of several attempts to provide general legislation for the protection of competition and was modeled after the pertinent EEC Treaty articles. Because of the prolonged debate over the several proposals presented, none has yet been enacted. ${ }^{95}$ Given the persistent politico-economic factionalism of the coalition governments; and given social status accorded those in the entrepreneurial class, divestment by large cartels and dominant firms is unlikely to be pursued very diligently. Moreover, the economic problems posed by small firms (thirty per cent of the Italian firms employ less than ten persons), sucl as underemployment because of low profit margins, low productivity, and high interest rates for investment borrowing (twelve per cent as agamst six per cent for larger companies), make it likely that cartelization will be encouraged rather than condemned. ${ }^{96}$ If industrialization is to be maintained, there must be an incentive to save and invest; this incentive has not yet been developed among smaller businessmen, especially in Southern Italy. ${ }^{.7}$

\section{European Coal and Steel Community}

The European Coal and Steel Community regulation of agreements under article 65 resembles the French regulation. In addition, it authorizes specialization agreements and rationalization agreements for the purpose of improving production and technological development. Even though article 65 forbids all agreenents which tend "directly or indirectly, to prevent, restrict or disort the normal operation of competition within the Common Market," ments are condoned. ${ }^{99}$ This attitude can be partially explained by the

92 Cóntce CrvILe arts. 2595-2620 (1942).

93 Venturini, supra note 50, at 646; Savastano c. Pratesi, Tribunale di Roma, Feb. 18, 1957, [1958] II Foro Italiano 302.

94 See [1960] II Foro Italiano IV 29.

95 Europe, Common Mkt. Daily Bull., May 25, 1964. See also Riesenfeld, supra note 86 , at 838 .

${ }^{90}$ Wellisz, The Coexistence of Large and Small Firms: A Study of the Italian Mechanical Industry, 71 Q.J. ECON. 116 (1957).

97 Italy: Myths and Truths, in Itary (Steel ed. 1963).

98261 U.N.T.S. 195 (1951).

99 Thus, of the 228 cases taken up as of January 31, 1964, only six agreements were pro- 
GEOR $G^{100}$ case, in which two selling agencies were each authorized to have a fifty per-cent share of Germany's Common Market coal sales. After World War II, the West German coal combine was broken into six separate sales organizations which established a common sales operation (Gemeinschaftsorganization Ruhrkohle) known as GEORG. While this joint operation could have been forbidden under article 65, it was tacitly allowed by the High Authority for the purpose of protecting the European coal market from cheaper coal imports. In May 1960 these organizations applied to form a single selling agency for the separate collieries. The High Authority rejected the application as being incompatible with article 65 of the ECSC Treaty. While the organizations appealed the decision to the Court of the Community, the High Authority attempted to revise article 65 to allow for authorization of certain agreements and joint selling agencies "even if they involved the allocation of markets, products, customers or sources of supply . . .".101 When the court rejected the appeal, ${ }^{102}$ as well as the attempted revision of article 65 by the High Authority, agreement was reached to form two separate selling agencies. Authorization of this agreement was conditioned upon the High Authority's power to intervene in the operational control of the cartel.

The High Authority, in discussing the court's decision, stated that the treaty:

recognizes that the technical economic trend is toward larger operation units, with the result that the coal market is becoming more oligopolistic than ever. Article 65(2) and Article 66(2) do not oppose this trend, provided the necessary minimum of competition among major units is preserved to satisfy the basic requirements of Article 2. This minimum is afforded where a joint selling agency is so organized as not to [contaim] ... the power to determine prices for a substantial part of the products in question within the Common Market. ${ }^{103}$

In other words, "minimum competition" could be approaching no

hibited. High Authortty, Twelfith General Report on tHe Activities of the CoMMONITY 190 (1964).

100 Décisions de l'Haute Authorité de la Communauté Européenne du Charton et de l'Acier, March 20, 1963, 6 J.O.C.E. 1173, 1191 (April 10, 1963). An appeal from the High Authority's decision was unsuccessful. Gouvernement du Royaume des Pays-Bas c. Haute Authorité de la Communauté Européenne du Charton et de l'Acier, Cour de Justice des Communautés Européennes, June 15, 1964, 10 Rec. de la Jurisprudence de la Cour 1047 (1964).

101 PEP 246.

102 Geitling c. Haute Authorité de la Communauté Européenne du Charton et de l'Acier, Cour de Justice des Communautés Européennes, May 18, 1962, 8 Rec. de la Jurisprudence de la Cour 171 (1962).

103 High Adthority, Eleventi General Report on the Activities of the CoMMTUNITY 45 (1963). (Emphasis added.) 
competition, while "substantial part of the products" might refer only to a complete monopoly. Hence, the GEORG result is not much of an improvement over pre-war national restrictive trade practices. One might even argue that the agencies possess more power over the market than they could have acquired prior to the establishment of the ECSC: the GEORG complex in effect is like a tariff barrier against the firms of non-Member States; these firms are now confronted with a cartel under the auspices of the High Authority.

\section{European Economic Community}

The foregoing synoptic interpretation of restrictive trade agreements leaves little doubt about the dissimilarities of regulation resulting from different attitudes toward competition annong the nations. It ranges in scope from complete dismterest about cartel agreements in Italy, to tacitly condoned cartels in the Benelux countries, to prohibitions of agreements that adversely affect prices in France, to specific production exemptions in Germany, to outright prohibitions in the United States. The procedures vary from controlled cartels in the European Coal and Steel Community, to authorized agreements in Germany and France, to supported agreements in Belgiun and the Netherlands, to compulsory agreements in Italy. These, then, are the differences in restrictive trade philosophies to be harmonized under article 85 of the Rome Treaty. Given the broad language of article 85 , the Commission will have to use it as a general guide for case-by-case interpretation, supplemented by the more specific national legislation that reflects the specific environinental conditions, if the objective of balanced expansion is to be attained.

Regulations 17 and 27, implementing articles 85 and 86, present a further difficulty in the harmonization process. Articles 9 and 10 of regulation 17 estabhsis dual competence between the Member States and the EEC Commission to enforce Treaty articles 85(1) and 86. The Commission is granted full dispensatory authority to allow cartel agreements upon notification by the firms applying for exemption. ${ }^{104}$ However, mucli of the Commission's power is curtailed by indirect powers of the Member States, since investigation and enforcement of established violations will often be executed by local authorities. "Notification camrot cure an infringement of the Treaty provisions, any more than failure to notify can create such an infringement."105 Thus the

104 Campbell, Regulations as to the Implementation of Articles 85 and 86 of the Rome Treaty, 2 INT'x \& Cosrp. LAW Q. 1027, 1028 (1962). Reg. No. 17, art. 13, 5 J.O.C.E. 208 (Feb. 21, 1962), authorizes the Commission to request Member States to carry out needed investigations.

105 Campbell, supra note 104, at 1027. 
Member States can weaken the EEC's dispensatory authority in two ways: either by not enforcing a decision of the Commission, or by omitting to notify the Commission of any infringement. "[T]he Commission lacks its own administrative inachinery ... [and] will normally request national authorities to carry out the investigations which it requires." 106 This is but one of many reasons why it seems unlikely that the EEC authorities will oppose national attitudes. Since it has no practical recourse should a Member State choose to circumvent its decrees, the Commission is likely to develop its policies so that they will least conflict with the various national concepts, even though the hoped-for degree of harmonization may not be achieved. However, the objective of harmonization should not be the uniform interpretation and apphcation of article 85 , but a flexible and varied usage of the law to improve the standards of hiving of the Member States.

\section{B. Dominant Positions}

Article 86 of the Rome Treaty provides that, "To the extent to which trade between any Member States may be affected thereby, action by one or more enterprises to take improper advantage of a dominant position within the Common Market or within a substantial part of it shall be deemed to be incompatible with the Common Market and shall hereby be prohibited." 107

It is significant that article 86 prohibits only the abuse of dominant positions and that, with the exception of section 1 (c) of article 85 , it hists the same examples of violation as does article 85 . One may assume therefore that the EEC does not consider dominant positions bad per se, but only insofar as they are abused..$^{108}$

Unike the United States, EEC Member States and the Higl Authority are very lenient toward dominant firm positions. The United States, in the Bethlehem Steel case, ${ }^{109}$ forbade a merger between Bethlehenu and Youngstown Sheet and Tube Co. on the grounds that the combination would control twenty per cent of the market and would thereby substantially lessen competition. (U.S. Steel already held thirty

106 Hontg, Brown, Gletss \& Htrsce, Cartel. Law of the European Economic Comaronitr 70 (1963).

107298 U.N.T.S. 48 (1958).

108 See Jornt Econ. Comar. 3.

109 United States v. Bethlehen Steel Corp., 168 F. Supp. 576, 585 (S.D.N.Y. 1958). The Court discounted the corporations' rationalization argument that competition would increase because of Bethlehem's more powerful position against the U.S. Steel Corporation. See generally Spier, The German Cartel Law: An Attempt to Eliminate the Restraint of Competition, 20 WASH. Bus. Rev. 19, 25 (1961). 
per cent). Monopolies are generally illegal per se; ${ }^{110}$ the fact that a monopoly went unchallenged for many years is irrelevant.

\section{Germany}

Germany's regulations on abuse of dominant positions list virtually the same examples as the EEC's articles 85 and 86 . Monopolies per se are not illegal, and mergers need be registered only when more than twenty per cent of the market or production is affected. However, registration gives the Cartel Authorities "no powers to act against these mergers." "111

The Daimler-BMW merger in 1954 provides ample evidence of this. ${ }^{112}$ With the acquisition of BMW, Daimler controlled over twenty per cent of the German automobile market, and moved into multiline commerce in plastics, steel, and iron in Belgium and France. Furthermore, Daimler-Benz controlled eiglity-eight per cent of the Auto-Union Corporation and had interests in Studebaker-Packard Corporation and in Itahan and French car manufacturers. Yet Daimler-Benz is a dwarf compared to Volkswagen, which controls forty-two per cent of the German market.

It is not so much the economic misuse of power which the German fears in concentrations, but the social and political by-products. "The concentration process can go unhindered" unless it abuses its powers. ${ }^{113}$

\section{France}

France, with its somewhat decentralized economy, actually encourages horizontal mergers. Only the recent Finance Act No. 63-628 (article 3) of July 2, 1963, ${ }^{114}$ attempts to prevent abusive pricing practices of a dominant firm by incorporating article 59 bis and ter and article 37(3) of the price ordinance on restrictive trade agreements. As with cartels, monopohes are not considered bad per se; only abusive monopohstic behavior is prohibited.

The main empirical test is the price level. Ideally, this is determined by the relationship between the effective seller's price and the price that would be set by perfect competition. In practice, however, the Tech-

110 See United States v. Aluminum Co. of America, 148 F.2d 416 (2d Cir. 1945).

111 PEP 217.

112 Spier supra note 109 , at 27.

113 Dürrhammer, The German Cartel Law and Concentration, 12 CARTEx, 26 (1962).

114 [1963] J.0. 5915; [1963] Bulletin Législatif Dalloz 326. For a comparative sumnary of legal provisions on market dominating enterprises, see OrGanIzaTION FOR EcONOMIC Cooperation and Developacent, Restrictive Business Practices: Comparative Sumamary of Legislation In EUROpe and North America (O.E.C.D. Pub. No. 16957 1964) 59, table VIII. 
nical Commission looks for more definable criteria, such as high profit margins. The standards for adjudication are set along the same lines as those for cartels; for this reason, monopolistic behavior is subject to the aforementioned Finance Act on cartel regulations. The Commission's other empirical tests for monopolistic behavior also indicate primary concern for the effect of monopoly on the national economy; for example, it assumes that there is a negative correlation between the variety and quality of products and the amount of monopoly power held by a firm. Reluctance to exploit technical discoveries and restraints on the entrance of new producers are also considered proof of illegal monopolistic behavior.

An example of French permissiveness toward mergers is the acquisition in 1965 of Kleber-Colombes by Michelin. ${ }^{115}$ The latter already held fifty-five per cent (approximately 250 million dollars in sales) of the French tire market and twenty-five per cent of the general European market. Acquisition of Kleber will give it roughly another 100 million dollars-in proportion to the 1964 sales rate-in rubber and plastic products. If one considers that Michelin already owned a fifty-five per cent interest in Citroen, it seems quite clear that the latest acquisition is not a national move to improve competition as envisioned by article 86. It looks more like a disregard of the Treaty's goal of harmonization. To the best knowledge of the author no legal action lias been taken.

\section{The Netherlands}

The Dutch provide relatively ineffective regulation of dominant positions under the Economic Competition Act of 1956/58. They mostly control any restrictive agreement between such firms and other enterprises. The Lijmar case, ${ }^{116}$ where abuse of a dominant market position was found to stem from an agreement between cigar wholesalers, supports this postulate. The Lijmar Co. was part of a group of affiliated wholesalers who were boycotted by supphers in sympathy with complaints from other, non-affiliated wholesalers. Lijmar filed suit against the suppliers, claiming the boycott was an abuse of a dominant market position. This abuse resulted in economic restraints upon the plaintiff. Althougl the suppliers' riglit to choose their chaunels of distribution was recognized, the agreement to boycott Lijmar was considered an abuse of the dominant position: The boycott prohibited Lijmar from practicimg its trade. ${ }^{117}$ In other words, the agreement played the more

115 Business Week, July 17, 1965, pp. 137-40.

116 Decision of the Minister of Economic Affairs, August 4, 1961, Nederlandse Staatscourant, August 7, 1961, p. 4.

117 See Mok, supra note 85, at 133-37. 
significant role than the factor of dominance; the dominant position per se was not questioned, but only its abuse.

\section{Belgium}

In the Belgian law, a dominant position is regarded as an abuse of economic power when it restricts the expansion of production or trade, ${ }^{118}$ or prejudices the public interest. ${ }^{119}$ Considering the average small, inefficient Belgian firm, concentration is more likely to be encouraged in the public interest than restricted. Moreover, economic interest groups exert considerable influence over the Belgian government. ${ }^{120}$ Given the present composition of these groups, it appears unlikely that the government will be encouraged to prohibit concentrations.

\section{Italy}

Italy does not consider dominant positions illegal. ${ }^{121}$ The latest revisions of the Colombo Bill on Italian antitrust regulation are such that, even if the Bill were now passed, the one article with real teeth concerning regulation of dominant positions will have been eliminated. Moreover, this bill now carries an amendment granting tax advantages to smaller companies that inerge. ${ }^{122}$ This attitude is not surprising. The inefficiency of the average Italian firn and the powerful pressure groups of existing conbines hardly provide a cliniate conducive to ostracizing cartels and dominant positions; rather, the chmate favors sucli ventures.

\section{European Steel and Coal Community}

The ECSC, under article 66 of the Paris Treaty, aims to curb concentrations ${ }^{123}$ and to prevent the misuse of power. ${ }^{124}$ The concept of concentration is not clearly specified. ${ }^{125}$ The High Authority retains the riglit to regulate dominant firms. ${ }^{126}$ Further, section 2 of article 66

118 PEP 225.

119 Act on Protection against Abuse of Economic Power, [1960] Moniteur Belge 4674; reprinted in $10 \mathrm{~W}$ WW 704 (1960). Governmental interest in the expansion in the economy is refiected in [1962] Serat de Beigique, Programane d'Expansion Economique.

120 See Chlepner, Cent ANs D'Histolre Soctale en Beigique 325-32 (1956).

121 Article 2597 of the 1942 Civil Code merely controls discriminatory dealings of legal monopolies. See Minniti c. Società Carisch, Tribunale di Roma, June 15, 1960, [1961] Il Foro Italiano 554.

122 Europe, Common Mkt. Daily' Bull., May 25, 1964.

$123 \S \S 1-6,261$ U.N.T.S. 199 (1951).

124 § 7, 261 U.N.T.S. 203 (1951).

125 See Riesenfeld, The Protection of Competition, in 2 AMrrican ENTErprise IN tHe European Common Market: A Legat Profite 197, 314-15 (1960).

126 Art. 66, §7. 
grants the High Authority the right to authorize dominant positions which it does not consider detrimental to competition; by section 3, the High Authority can exempt from the requirement of prior authorization those transactions which in its opinion "conform to the conditions required by section $2 . "$

The High Authority has taken advantage of these provisions. "[T]he High Authority does not object to useful concentrations, and indeed encourages them in every respect,"127 as long as it can retain part of the operational control over the firms. The Thyssen-Phoenix merger, which was concluded and authorized by January 1964, involved better than twenty per cent of West German steel production. The merger, which made Thyssen the largest steel combine in the Common Market, indicates the latitude of the High Authority regarding dominant positions. As one observer noted, "It is hard to beheve that this latest steel merger is necessary in order to increase the efficiency of the Community's steel production. ${ }^{\prime 128}$ Indeed, the aim toward productive efficiency seems to have ignored the effects of the merger on competition.

There appear to be two interesting developments from this case: First, concentration may actually be desirable; second, concentrations are permissible as long as the High Authority can stipulate that it may interfere in the practices of the combine in order to prevent grossly abusive actions. Given the past and present record of the High Authority, the right to interfere amounts at best to hp service.

The present performance of European antitrust regulation suggests that mergers and monopolies are generally acceptable. One might even assunie that as long as no gross abuse is evident, many firms desiring to continue restrictive agreements forbidden under article 85 of the Rome Treaty may circumvent potential infringements of this regulation through merger or acquisitions as a substitute for cartels, simce the apphication of article 86 may be more lenient.

In summary, mergers and monopohes are generally acceptable under present European antitrust regulations. It is questionable whether intplementing regnlations for article 86 will bring forth more severe restrictions. However, one may safely state that, given the present economic and pohtical conditions in Europe, dominant positions will be permitted to continue for some time to come. First, regulation 17 does not indicate that the Commission is authorized to examine a prospective market merger - as a substitute for cartel practices-to determine if there may be a potential for abuse. Second, many EEC regions such as

127 High Authortty, Third General Report on the Actrvities of the CoManunity 117 (1955).

128 Reconcentration in Steel, 14 CARTEL 79, 81 (1964). 
Southern Italy and Belgium actually require the preservation and encouragement of dominant positions to achieve a balanced expansion in the Community. Thus, any forthcoming EEC legislation on dominant practices is hikely to allow the Commission to vary, through case-bycase interpretation, its remedies to take into account local needs.

\section{III}

\section{THE GRUNDIG-CONSTEN DECISION}

The Grundig-Consten case ${ }^{129}$ is the first decision by the Commission of the European Economic Commumity under article 85(3) since the promulgation of regulation 17. Presumably, the decision indicates "the attitude which the Commission will take with respect to the exploitation of industrial property rights . . . and exclusive distributorship agreements."130 This view of the Commission's attitude may not be entirely accurate; in accord with this author's hypothesis, the decision gives evidence that the Commission will decide cases in light of national attitudes reflected by national antitrust legislation.

Grundig, the sales subsidiary of the German manufacturer of Grundig Radio and Electromic Equipment, contracted with a French importer, Ets. Consten, for the sale of Grundig products by Consten in France, the Saar, and Corsica. The three basic conditions of the agreement were: (1) that Consten would have sole distributorship of Grundig products in France, (2) that Consten would not sell competitive products in France, and (3) that the Grundig trademark "GINT" could be used in France for its products only if they were sold through Consten.

The Commission prohibited the agreement on the grounds that it violated article $85(1)$, since it gave Consten a virtual monopoly with respect to other French importers in the sales of Grundig products. Although the Commission did not specifically refer to the above mentioned conditions, it based its decision on the effect of the sales monopoly resulting from them. The Commission viewed the agreement as one primarily affecting France rather than Germany. The French attitude toward monopoly-as reflected in its Finance Act-is concerned primarily with price effects upon the national economy. Vertical agree-

129 Decision of the Commission, Sept. 23, 1964, 7 J.0.C.E. 2545 (1964). The French Court of Appeals reversed a lower court's decision for Consten; the Court, however, suspended its judgment, pending a decision by the EEC Commission. Société Union Nationale des Economies Familiales c. Consten, Cour d'Appel de Paris, Jan. 6, 1963, [1963] Rec. Dalloz Jurisprudence 189. On Dec. 12, 1964, Grundig appealed the decision of the EEC Commission. 8 J.O.C.E. 21 (1965). This may force the EEC Courts to take a closer look at the politicoeconomic consequences of the decision in Germany, which so far lave been ignored.

130 Newes, The European Commission's First Major Antitrust Decision, 20 Bus. Law 431 (1965). 
ments are generally considered to affect prices adversely and, therefore, to destabilize the French economy. Moreover, the French version of the EEC regulation states that restrictive trade practices are in violation of the Treaty if they "tend" to lessen competition. Thus, vertical agreements producing a monopoly that "tends to affect prices" of the French national economy would be prohibited outright. The Commission, in prohibiting the agreement because it tended to lessen competition, clearly applied article 85(1) in the light of French economic, social, and political conditions. ${ }^{131}$ Significantly, the agreement's effect on the French price levels and productive efficiency was of greater concern to the Commission than the alleged potential increase in trade between the Member States. ${ }^{132}$

The economic consequences of the Grundig-Consten agreement justified the apparently severe apphication of article $85(1)$; the exclusive dealership adversely affected part of the Common Market economy. One slould not project from this case, however, that other exclusive distributorships or exploitations of tradenarks will be similarly restricted. The saine economic and social considerations will have to be present..$^{133}$ The Commission was concerned with the actual effects upon the French econoiny ensuing from the three conditions of the agreenent rather than with the legal terms of the agreement itself. The Commission's

131 This hypothesis finds support in the Commission's rejection of the applicants' rationalization argument that their merger would improve consumer prices and products. The Commission noted that consumer prices did not improve. Moreover, the Commission assumed that the agreement as to the use of the trademark "GINT" could in fact reduce productive efficiency rather than improve it. The Commission specified, however, that the exemptions under article 85(3) did not apply because the agreement passed no profit on to the consumer and included provisions making the exclusive territorial riglit indispensable. The Commission felt that the exclusive territorial provision was an unnecessary restriction.

132 From a purely legal interpretation of article $85(1)$, the decision in the GrundigConsten case appears to be inconsistent with the preceding Grossfillex case. Decision of the Commission, March 11, 1964, 7 J.O.C.E. 915 (1964). See Deringer and Tessin, Commentary to the Grundig-Consten case, Oct. 16, 1964, (unpublisled commentary at University of California Law School) 5. It becomes more consistent, however, when viewed within the context of French national policy. Althougl the legal aspects of the contract of the Grossfillex case present an exclusive dealership similar to that of Grundig-Consten, they embody divergent economic consequences. In the Grossfillex case, the exclusive distributor was a Swiss firm, while the seller was French. This constitutes a significant difference from the Grundig-Consten case because the exclusive-right-to-sell clause applies to the territory outside the Common Market. Therefore, any potential detrimental effects upon competition would more likely occur outside the Common Market, with hittle if any distortion of competition for the French Member State. No mention was made of possible distortion of competition resulting from restriction of French dealers to export Grossfillex products to Switzerland. Compare Décision Ministérielle, Entente Entre Fabricants de Verre Plat, CosaM'N Rep. 36.

${ }^{133}$ Deringer and Tessin, supra note 132 , at 8. 
attitude seems to represent a departure from the European legal tradition since it represents a movement toward decisional law. ${ }^{134}$

\section{CONCLUSION}

A country's regulations dealing with competition reflect its political and social norms and economic needs. When the social, political, and economic environments differ among countries, their philosophies and consequently their regulations of competition will differ also. The German concept of competition rationalizes vertical cartel agreements and mergers for the pursuit of increased productivity. Competition in the French plamied economy centers around stable price levels, aiming for consolidation of unproductive enterprises and prohibiting vertical agreements in order to prevent inflation. Export dependence and the small market size of the Benelux economies produce a more liberal attitude toward restraint of competition, permitting cartels and dominant position enterprises if they further the public interest. Italy's virtual absence of regulations agamst restrictive trade practices depicts the difficulties of its economic dichotomy, political fragmentation, and governmental interferences.

Given the different environments of its Member States, the EEC's supranational regulation of competition must be guided by more than the bare wording of articles 85 and 86 and their implementing regulations.

134 Two recent cases involving exclusive dealership arrangements support the author's hypothesis. In Diepenbrook and Riegers N.V. of Ulft-Blondel S.A., BNA, ANTITRUST \& Trade REg. REP., Aug. 3, 1965, p. A-11, the Dutch manufacturer of household wares gave a French distributor sole selling rights within France, but no restrictions were placed upon re-exports of the Diepenbrook products froin France by third parties nor upon imports of competitive products to France by the French distributor. The Commission in allowing the agreement to stand reasoned that exclusive dealerships did not per se contravene article 85 of the Rome Treaty unless the dealership would make it possible for the differences in price levels in the Member States to be maintained even after completion of the Common Market. As in Grundig-Consten, the effect of the agreement on prices seems to have been dominant in the Commission's decision.

In Hummel-Isbecque, BNA, ANTItrust \& Trade REć. Rep., Nov. 2, 1965, p. A-3, the German manufacturer of garden tractors gave exclusive dealership rights to a Bclgian distributor. The contract excluded other potential distributors from importing the manufacturer's products. Yet the Commission in allowing the dealership to continue, stated that the agreement provides consumers with better service, has not led to higher prices, and allows for exports of the manufacturer's products to Belgium through third-party countries. Although the Commission admitted that the agreement could result in distortion of competition, it felt that the benefits accruing to the consumer would outweigh the detriment. The Commission's action indicates a primary concern with the economic and social condition of Belgium rather than with the terminology of article 85 . This attitude accounts in part for the variance in outcome from the Grundig-Consten case. Further, the Diepenbrook-Blondel and the Hummel-Isbecque decisions suggest, as did the GrundigConsten decision, that the Commission will evolve legal principles through the decisional method. 
The Rome Treaty's goal of balanced expansion requires that the EEC use its regulations only as a guide in rendering decisions. The economic and pohtical conditions reflected in the national laws regulating competition will therefore provide a more accurate means for accomplishing this goal and will serve as a better measure for future Commission decisions.

\section{APPENDIX}

The following pages provide a summary of the concept of competition for each Member State of the European Economic Community. The respective political, social, and economic environments, from which the concept of competition evolves, are presented in order to understand the national regulations on restrictive trade practices. The national laws are then contrasted to the Common Market laws to illustrate the problems of reconciling national and supranational laws.

\section{I \\ FRANCE \\ A. The Environmental Bases of Competition}

Characteristics of the social environment in France have been (1) stagnation of population, (2) a pre-war predominance of family firms, and (3) postwar mass employment in concentrated industry.

The political environment has been marked by (1) freedom of contract (Napoleonic Code), (2) a resurgence of nationalism, and (3) national economic planning.

Distinct elements of the French economic environment have been (1) the effects of the 1930's depression, (2) a stagnation of demand, (3) existence of small economic units, (4) high tariff protection, (5) use of heavy cartelization

1 for purposes of price stability, (6) government planning of the economy, (7) existence of the escalator wages clause and its effect on inflation, and (8) limited resources for investment.

\section{B. French Concept of Competition}

Given the social, political, and economic environmental characteristics above, the French concept of competition has come to center around (1) a distinction between concentrated power, desired in itself, and collusive behavior detrimental to the economy, (2) the idea that lower production costs must benefit the economy through lower prices, (3) the use of concentrated industry for efficiency, (4) the prevention of inflation, (5) the belief that price competition must exist, and (6) the credo that restrictive practices inust be consistent with the plan of the "economie concertée."

\section{The Law}

\section{Attittude toward Cartels}

(a) French Law.-The basic criterion in applying the law is the effect on prices; cartels which raise prices, thereby inducing inflation, are considered to be an abuse. Cartels can be justified only by their beneficial effects on the economy.

The following are the basic French laws on restrictive trade practices. (1) 
Price Ordinance No. 45-1483 of June 30, 1945 (as amended), particularly article 37 which prohibits such practices as refusal to sell and discrimination in price and terms (section 1a), tying agreements (section 1c), the prohibitions outlined under article 59 bis (section 3 ), and minimum price maintenance and price fixing (section 4). (2) Decree No. 53-704 of Aug. 9, 1953, re-enacted and amended by Decree No. 58-545 of June 24, 1958, provides for the prohibition of any cartel hindering tle reduction of, or artificially raising, prices (article $59 \mathrm{bis}$ ), the exemptions such as autlorizations (article $59 \mathrm{ter}, 1$ ) and rationalizations to promote economic progress (article $59 \mathrm{ter}, 2$ ), and the establishment of a Technical Commission for enforcement and investigation (article 59 quater).

(b) Relation to Common Market Laws.-There are four important points of comparison between the French and the ECSC and EEC laws. (1) Agreements which restrict the operation of competition, especially those wlich fix prices, share markets, or limit production, are prohibited. French law prohibits these practices a posteriori, whereas the Common market laws prohibit them a priori (EEC article 85(1), (2) and ECSC article 65(1)). (2) In the EEC, registration for exemption from Rome Treaty article $85(1)$ is required (EEC regulation 17, articles 2, 4, and 5) and in the ECSC prior authorization of agreements is mandatory (ECSC article 65(2)). France has no process for registration or prior autliorization. (3) EEC article 85(3) and ECSC article 65(2), as well as the French law, exempt agreements contributing to economic progress. The French exemptions are automatic; the Common Market requires prior autliorization for validity. (4) EEC regulation 17, article 4 and ECSC article 65 allow verticle price maintenance in limited situations; the French law strictly prohibits this practice.

\section{Attitude toward Concentrations}

(a) French Law.-The French consider concentrations to be intrinsically good: They promote efficiency and price competition, but they must not abuse their position by causing price inflation. Concentrations are regulated by the Finance Act No. 63-628 of July 2, 1963; section 3, which provides that the activities of enterprises or groups of enterprises loolding a dominant or monopoly position which have the object of interfering with the normal operation of the market are subject to the provisions of article 59 bis, ter, and quater and article 37(3) of Ordinance No. 45-1483 (as amended). See law under cartels.

(b) Relation to Common Market Laws.-(1) EEC article 86 prohibits a priori the following abuses by a dominant firm: price fixing, himiting production, discrimnation, and tying devices. Witl the exception of limiting production, the French law is similar in scope. (2) Criteria for EEC article 86 and ECSC article 66 are based on restriction of competition in general, whereas in France criteria are based primarily on price. (3) ECSC article 66 (1) requires registration of new concentratious. Neither France nor the EEC has provisions for registration or prior authorization.

II

WEST GERMANY

\section{A. The Environmental Bases of Competition}

The social environunent in Germany has four inajor characteristics. (1) The bases of social values are: security, stability, orgamization, order, and per- 
formance. (2) There is a strong desire for productive capacity. (3) Monopoly power is judged according to its infringement upon social and political liberties. (4) There is a high regard for the law.

The political environment is characterized by (1) limited freedom of contract, (2) government intervention in business to prevent ruinous competition, (3) bureaucratic organization of government, and (4) public acceptance of governmental authority'as guardian of political and social freedom.

There are five points to bear in mind about the German economic environment. (1) The attempts of the Allied Authority to eliminate pre-war cartels and concentrations were not successful. (2) Concepts of competition range from the neo-liberal school of "social market economy" to protection of restrictive trade practices. (3) There is limited state intervention in economic affairs. (4) There has been accelerated growth of capital goods output. (5) Exports are of primary importance.

\section{B. German Concept of Competition}

Cartels and concentrations are considered desirable for efficiency of production, although they must be controlled if they abuse their power and upset the order of the "social market economy." Price equilibrium is maintained in the interest of stable production.

\section{Attitude toward Cartels}

\section{The Law}

(a) German Law.-In assessing the value of cartels in Germany, the following points are important. (1) Agreements are justified only if they raise the efficiency of production and contribute to an ordered expansion of capacity. (2) The basic criteria are efficiency of production and a stable economy. (3) Resale price maintenance of branded goods is upheld.

Section 1 of the Act Against Restraints of Competition of July 27, 1957, sums up part of the above by providing that horizontal agreements which adversely influence production or economic conditions are invalid. There are, however, many exceptions to this basic rule: (1) section 6(1)-agreements to engage in exports (pure export cartels), (2) section 5(4)-agreements to standardize specifications or itemize prices, without price fixing (quotation cartels), (3) section 2(1)-agreements to apply uniform trade terms (conditions cartels), (4) section 3(1)-agreements to regulate legitimate rebates (rebate cartels), and (5) section 5(1)-agreements to regulate standards (standardization cartels). Prior authorization by the Cartel Authority is required for agreements to (1) adjust capacity for the welfare of the economy (structural crisis cartels) section 4 ; (2) enhance productive capacity (rationalization cartels)-section $5(2)$, (3); (3) engage in export affecting domestic trade (export cartels with internal ramifications)-section $6(2)$; (4) regulate imports not open to domestic competition (import cartels)-section 7; and (5) protect the national economy (emergency cartels)--section 8(1), (2). The power to exempt under section 8 is reserved to the Minister of Economics rather than the Minister of Justice.

Section 15 of the Act provides that vertical agreements are null and void if they restrict a party's freedom to determine prices, terms, and conditions of trade with third parties. Again, there are notable exceptions in subsequent sections such as (1) sections 16 and 17-branded goods, requiring prior authorization of the Cartel Authority, (2) section 18-exclusive dealing arrange- 
ments which can be invalidated if they restrict the freedom of one of the parties, and (3) sections 20 and 21-restrictions attached to the transfer of patent rights.

(b) Relation to Common Market Lares. - There are five important points of comparison between German and the Common Market laws. (1) Agreements which restrict the operation of competition, especially those which fix prices, share markets, or limit production, are prohibited (EEC article $85(1,2)$ and ECSC article 65(1)). Although German law does not enumerate specific practices, its apphication is based on the criteria of restrictions on competition and production, similar to the Common Market laws. (2) Registration for exemption is required under EEC regulation 17, articles 2, 4, and 5, and prior authorization of agreements is mandatory under ECSC article 65(2). The German Cartel Authority requires registration of all agreements, similar to the EEC law, but also requires specific authorization of agreements directly affecting the domestic economy, similar to the ECSC law. (3) EEC article 85(3) and ECSC article 65 (2) allow for exemption of agreements that contribute toward economic progress. In German law, exemption for rationalization requires prior authorization of the Cartel Authority, analogous to the ECSC law. However, the German list of exemptions is more extensive and detailed. (4) EEC regulation 17, article 4 (11) (a), allows vertical price maintenance agreements between two firms within one Member State. In German law, this practice is allowed for branded goods, but requires prior authorization of the Cartel Authority. (5) With respect to coverage and identity of provisions, more than any other EEC nation, Germany's law approximates the Common Market laws.

\section{Attitude toward Concentrations}

(a) German Law.-Two points stand out as descriptive of the German attitude toward concentrations. (1) Acts of concentrations which do not upset the order of the "social market economy" are encouraged for purposes of improving productive capacity. (2) The law is applied a posteriori for abuse of dominant positions.

Specific laws on concentration are to be found in the Act Against Restraints of Competition of July 27, 1957. (1) Dominant firms which abuse their power by manipulating prices, imposing terms, or by tying agreements may have their contracts invalidated or may become subject to orders of the Cartel Authority (section 22(3)). (2) Concentrations controlling twenty per cent or more of the market must register with the Cartel Authority (section 23). (3) Firms or groups of firms may not induce other firms to refuse to sell or purchase with the intent of harming a competitor (section 26(1)). (4) Dominant firms must neither hinder other firms in their business activities, nor discriminate as to conditions of sale or prices between similarly situated firms (section 26(2)).

(b) Relation to Common Market Lawes.-There are three important points of comparison between German and the Common Market laws. (1) Under EEC article 86, acts of dominant firms which fix prices, limit production, discriminate, or use tying devices are prohibited. Under ECSC article 66, authorization will be granted to concentrations if they camot restrict competition. Like the EEC law, the German law prohibits abuses of a dominant position a posteriori; it is also similar to the ECSC law in that large firms are required to register with the authorities. In German law, however, the Cartel Authority 
does not have the power to order divestiture. (2) In both the Common Market law and the German law, the criterion for control by government authority is the abuse of market power by a dominant firm. (3) The German law is more extensive in its enumeration of practices that constitute abuses of power than is EEC article 86 or ECSC article 66.

\section{III}

\section{THE NETHERLANDS}

\section{A. The Environmental Bases of Competition}

The social environment of The Netherlands is characterized by (1) a predominance of family-owned firms, (2) rapid growth and high density of population, and (3) dependence on agriculture.

Significant elements of the political environment are that (1) political patterns are dictated by export policy, (2) there is limited government intervention in business affairs, and (3) restrictive trade policies are administered by the Minister of Economic Affairs.

In the economic environnent, the following points are noteworthy. (1) The economy is agrarian. (2) There has been a recent trend toward industrialization and manufacturing. (3) Areas of economic importance are near the sea due to the iniportance of shipping. (4) There is heavy dependence on both exports and imports. (5) Economic ties with Indoneisia are gone. (6) There are inflationary pressures from heavy domestic investment and industrial growth.

\section{B. The Netherlands' Concept of Competition}

From the above factors, competition in The Netherlands has come to nean the following. (1) Restraints of competition are neither good nor bad in themselves. (2) Cartels which serve the "general interest" are allowed and can be made compulsory. (3) The law is a tool for the Dutch export policy.

\section{The Lare}

\section{Attitude toward Cartels}

(a) Dutch Law.-In The Netherlands cartels are considered neutral-the state of the economy determines their permissibility. Nevertheless, registration is required. The criterion in deciding whether a cartel is justified is the general interest.

The following pertinent points of law are in the Economic Competition Act of June 28, 1956, as amended by the Act of July 16, 1958. (1) Regulation of competition is defined as any cartel or decision subject to civil law (section 1). (2) Cartels are required to register with the Minister of Economic Affairs (section 2). (3) Conditional exenıtion from registration may be granted (section 4). (4) At the request of a member, cartels can be made generally binding for three years on all members of an industry-in the "general interest" (sections 6-9). (5) Invalidation of classes of cartels is authorized if that class is contrary to the "general interest" (sections 10-15). (6) Invalidation of particular cartels is authorized if they are contrary to the "general interest" (sections 19-23).

(b) Relation to Common Market Lawes.-There are four important points of comparison between the Dutch and the supranational laws. (1) Under EEC 
article 85(1), (2) and ECSC article 65(1), agreements which restrict the operation of competition, especially those which fix prices, share markets, or limit production, are prohibited. In Dutch law, no agreement is directly prohibited per se, illegal practices are not enumerated, and the criterion is the "general interest." (2) Under EEC regulation 17, articles 2, 4, and 5, registration of cartel agreements is required, somewhat similar to the Dutch provisions. (3) EEC article 85(3) and ECSC article 65(2) allow agreements contributing to economic progress. The Dutch law merely allows the formation of compulsory cartels that are in the "general interest." (4) EEC article 85 and ECSC article 65 prohibit cartels a priori, but provide exemptions; the Dutch only require a priori registration, regulating abuse of agreements in the "general interest."

\section{Attitude toward Concentrations}

(a) Dutch Law.-Two major points characterize the Dutch attitude toward concentrations. (1) Small domestic demand and export competition produce a need for dominant firms. (2) Abuse of the "general interest" is the criterion for regulation.

Included in the Economic Competition Act of June 28, 1956, as amended, are the following regulations. (1) A dominant position is defined as a factual or legal influence on the market (section 1). (2) If dominant positions abuse the "general interest," the Minister of Economic Affairs can require abstention from activities detrimentally affecting the inarket (section $24 \mathrm{lb}(1)$ ), require the enterprises to supply goods to designated persons (section $24 \mathrm{lb}(2)$ ), apply rules concerning prices (section $24 \mathrm{lb}(3)$ ), and apply rules concerning trade terms (section $241 \mathrm{~b}(4))$. (3) The maximum duration of these orders is five years (section 24(2)).

(b) Relation to the Common Market Laves.- In comparing the Dutch regulations to their supranational counterparts, there are three important points. (i) EEC article 86 prohibits a priori the following abuses by dominant firms: price fixing, limiting production, discrimination, and tying devices. The Dutch law is similar but does not enumerate specific acts of abuse or require registration as does ECSC article 66. (2) EEC article 86 and ECSC article 66 specify that the criterion for judgment is the restriction of competition; this is similar to the Dutch criterion of "general interest." (3) Under EEC regulation 17, article 3 , the Commission can oblige firms to put an end to infringements; under article 15 of regulation 17, it may impose fines for violation of the treaty article 86. Under ECSC article 66(6), the High Authority may impose fines and, under article 66(7), it may fix prices, conditions of sale, and draw up production and dehvery programs for firms violating or failing to carry out an authorization under article 66. Dutch law provides the Minister of Economic Affairs with sanctions almost identical to those of the ECSC.

IV

\section{BELGIUM}

\section{A. The Environmental Bases of Competition}

Belgium's social environment is best described by the following. (1) There is a predominance of family-owned firms. (2) The small size of the country and the influence of other nations produce heterogeneous social belavior. (3) There is marked influence of monarchy ownership. 
There are three major characteristics of the political setting. (1) Freedom of contract and association is upleld. (2) The Mimister of Economic Affairs interprets competition. (3) Anticompetitive measures and compulsory cartels are prevalent.

In the economic setting, five points stand out. (1) The many small production units are inefficient. (2) There is scarcity of domestic working capital and a tendency toward deflation. (3) The influx of "foreign investment is strong. (4) Insufficient domestic demand creates dependence on exports, thus discouraging active competition. (5) Cartels are an economic necessity.

\section{B. The Belgian Concept of Competition}

As a result of the above influences, the Belgian concept of competition can be summarized by the following four points. (1) Cartels and concentrations, because they may improve competitive conditions, can be inade compulsory. (2) Competition between producers is discouraged, thougl it is encouraged between distributors. (3) Any restrictive practice will be allowed if it is not contrary to the "public interest." (4) The "public interest" is generally synonymous with the producer's interest.

\section{The Law}

\section{Attitude toward Cartels}

(a) Belgian Law.-Cartels are encouraged in order to inaintain the economy's export competitive position. They can be made compulsory for the stability of the economy. The criterion for allowing a cartel is the public interest.

The Royal Decree No. 62 of January 13, 1935, authorized the formation of compulsory cartels encompassing all producers in a branch of trade in the interest of national stability. This law is still in effect. The Act on the Protection against the Abuse of Economic Power of May 27, 1960, prohibits cartel practices which abuse economic power. No provision is made, however, for the direct regulation or registration of cartels. There is no official list of illegal practices or abuses.

(b) Relation to Common Market Lares.-Under EEC article 85(1), (2), and ECSC article 65(1), agreements which restrict the operation of competition, especially those which fix prices, share markets, or limit production, are prohibited. In Belgian law, no agreement is directly prohibited, illegal practices are not enumerated, and the criterion is the "public interest."

In EEC regulation 17, articles 2, 4, and 5, registration is required, and in ECSC article 65(2), prior authorization of agreements is mandatory. Belgian law has no provision for registration or prior authorization. In contrast to Belgian law, EEC article 85 and ECSC article 65 prohibit cartels a priori but provide exemptions.

\section{Attitude toward Concentrations}

$\bullet$

(a) Belgian Law.-The political, social, and economic environments outlined above have led to the following Belgian attitudes toward concentrations. (1) Concentrations and dominant firms are encouraged for efficiency in export. (2) Only those acts of dominant firms which abuse the "public interest" are illegal.

Specific laws exemplifying this attitude are found in the Act on Protection 
against Abuse of Economic Power of May 27, 1960. (1) Economic power is defined as the power possessed by a dominant firm or association of firms (article 1). (2) Abuse is defined as a prejudice of the "public interest" (article 2). The law defines abuse by means of this general formula and omits listing any specific practices. Interpretation and application of the law rest in the Council for Economic Disputes through its informal inquiries.

(b) Relation to Cômmon Market Laws.-There are three important points of comparison. (1) EEC article 86 prohibits a priori the following abuses by a dominant firm: price fixing, production limiting, discrimination, and tying devices. The similar Belgian law does not enumerate specific acts of abuse. (2) In ECSC article 66(1), registration of new concentrations is required. Belgian law makes no provision for registration. (3) Under EEC article 86 and ECSC article 66, the criterion is the restriction of competition, similar to the Belgian criterion of "public interest."

\section{$\mathrm{V}$}

IUXEMBOURG

Because of Luxembourg's small size and close ties with Belgium, its restrictive practice laws follow very closely those of Belgium. The Grand Ducal Decree of January 22, 1936, "protecting producers, merchants, and consumers against certain activities tending to falsify the normal conditions of competition," was modeled after a Belgian ordinance of 1934. Resale price maintenance and exclusive dealership arrangements have been upleld. Similarly, the Law of July 31, 1929, was enacted to encourage the formation of holding companies through special tax advantages and exemptions. A general principle of neutrality toward restrictive practices has been followed.

\section{VI \\ ITALY \\ A. The Environmental Bases of Competition}

Italy's social setting is characterized by (1) rapid growth of population, (2) high propensity to consume, (3) social value placed in individual entrepreneurship, and (4) general disregard for the law.

Earmarks of Italy's political environment are (1) abolition of the corporate state, (2) political nepotism and instability, (3) factionalism, (4) a large degree of government participation in business, and (5) guarantee of freedom of contract.

Typical of the Italian economic setting are (1) the dichotomy between the underdeveloped agricultural region of the South and the heavily industrialized sector of the North, (2) the lack of domestic investment and lack of competitiveness in world trade, (3) the mass cartehzation of industry, and (4) the goverument ownership and intervention in business.

\section{B. The Italian Concept of Competition}

Five major points depict the Italian concept of competition. (1) Competition connotes the survival of the most powerful. (2) Economic progress is synonymous with concentration and cartelization. (3) Monopoly positions are allowed to exist. (4) The right to restrict trade has been upheld by the courts. (5) The government reserves the right to intervene in economic development. 


\section{Attitude toward Cartels}

\section{The Law}

(a) Italian Law.-The very hiberal attitude of the Italians toward cartels is depicted by the fact that (1) freedom of contract is upheld by the courts, (2) cartels of all types are condoned, and (3) generally, there are no norms for the regulation of competition.

There are few laws pertinent to the control of cartels. These are found in the Civil Code, Decree No. 262 of March 16, 1942. (1) Competition cannot injure the interest of the national economy (article 2595). (2) Agreements must be in writing and in a defined area of trade to be valid (article 2596). (3) Acts of unfair competition exist if any person imitates products or uses the name of a competitor, disseminates libelous imformation, or does not use ethical professional behavior (article 2598).

(b) Relation to Common Market Laws.-Italy has no specific restrictive business practice legislation, nor has it established any consistent norms for dealing with cartels and dominant firms. Insofar as the absence of any antitrust legislation tends to create a general pro-trust attitude, Italian policy is contrary to the policy of the Common Market laws. However, a bill on "the safeguarding of freedom of competition" was presented to the Chambers on February 24, 1960. This bill and other bills are now in debate.

\section{Attitude toward Concentrations}

(a) Italian Law.-The Italians feel that (1) concentrations are intrinsically good-they promote efficiency and generate investment funds for economic progress, and (2) tax advantages for mergers, financial trusts, and government ownership concentrate power in the hands of a few.

There is no law regulating concentrations or dominant firms. The Civil Code protects concentrations against the eroding effects of ruinous competition (see Decree No. 262, article 2598).

(b) Relation to Common Market Lares.-See same heading under cartels.

\section{BIBLIOGRAPHY FOR APPENDIX}

FRANCE

Ehrafana, Organtzed Bustess in France (1957).

JeANNENEy, Forces et Fatblesses de I'Economere Francaise 1945-1956 (1956).

Sheafan, Promotion and Control of Industry in Postwar France (1963).

Lavau, Political Pressures by Interest Groups in France, in INTERest Groups on Four

ConTINENTS (Ehrmann ed. 1960).

Macridis, France, in Modern Polrticat Systexs: Europe (Macridis and Ward eds. 1963).

\section{GERMANY}

Office of International Regional Economics-Europe Division, Basic Data on the Germatin Economy of the Federal Repubic of Geracany (U.S. Dep't of Comm., No. ORB-63-156 Dec. 1963).

WaItich, Matnsprings of the German Revival (1955).

Deutsch, The German Federal Republic, in Modera Politrcal Systems: Europe (Macridis and Ward eds. 1963).

Cartel Policy and the Common Market, 28 Potiticax and Econonac Piannavg 206 (1962). 


\section{THE NETHERLANDS}

Barnouw, The Land and People of Holtand (1961).

Lewandowsky, Recent Trends in the Dutch Economy, 20 THE WORLD TODAy 403 (1964). Schorr, The Dutch Way of Life, in Benexux 1958 (Fodor ed. 1963).

\section{BELGIUM}

De Vleeschadwer, L'Organisation Professionnetre de t'Economie (1950).

Internationat Reports on Factors in Investarent Bemavior (Williams ed. 1962).

Semat de Bexgique, Programare d'Expansion Economatque (1962).

Van KaIKes, Historre de IA BeIgique (1954).

Romanis, Economic Program and Recent Financial Policies in Belgium (Staff Papers, International Monetary Fund, March 1964).

L'insuffisance des investissements, motif de l'insuffisance de l'expansion Belge, 1961 Camrers ECONOMTQUES DE BruXeties 493.

\section{ITALY}

Lutz, Itady: A Study in Economic Devetopacent (1962).

ITAIY, (Steel ed. 1963).

VOTAX, THE SIX LEgGed DOG (1964).

Barzini, The Italian Character, Harper's, Aug. 1964, p. 33.

Italy's Mezzogiorno, The Economist, May 18, 1963, p. 668.

Chenery, Development Policies for Southern Italy, 76 Q. J. of EcoN, 515 (1962).

Pitiglini, The Development of Italian Cartels under Fascism, 68 J. OF Por. Econ. 375 (1940).

Sterling, Apertura a Sinistra: Second Round, Reporter, Nov. 21, 1963, p. 28.

Italy's Power Nationalization, The Economist, June 23, 1962, p. 123. 